\title{
Media-Coverage-Related Investor Sentiment during the COVID-19 Pandemic
}

\author{
Esra BULUT ${ }^{1}$, Seval AKBULUT BEKAR ${ }^{2} \odot$, Gülay ÇizGici AKYÜZ $\odot$
}

\begin{abstract}
This study tests the relationship between investor sentiment generated by COVID-19-related media coverage and BIST100 Index returns. In this context, the study is based on the ground laid by Tetlock's (2007) study, which stated that media content and stock market activity are correlated. The effect of investor sentiment on the BIST 100 Index is examined in this study for the period 11 March 2020 - 19 August 2020 through the news on the COVID-19 pandemic. In this context, panic, fear, media coverage and vaccine indices are used in the study as investor sentiment proxies based on media coverage of COVID-19. The Dolado-Lütkepohl causality test and the ARDL method were used to investigate the effects of indices on the BIST100 Index return and subsequently, the cross-correlation relationship has been examined to check the robustness of the results. It is found that media-coverage-based investor sentiment indices are related to BIST100 Index returns. However, our evidence does not support investor sentiment theory.
\end{abstract}

Keywords: investor sentiment, behavioural finance, BIST100, media coverage, COVID-19

Classification codes: $\mathrm{G} 10, \mathrm{G} 40, \mathrm{G} 14$

\section{INTRODUCTION}

In recent years, the potential linkages between investors and returns from a behavioural finance perspective have become an important research area. Investor sentiment, which is an overlooked phenomenon in traditional finance theories, is a very hot topic for behavioural finance researchers. De Long et al. (1990) provide a theoretical framework that describes the significance of investor sentiment in determining stock prices. Shleifer and Summers (1990) suggest a different approach to the efficient-markets approach which is based on investor sentiment and limited arbitrage. They show that investors who base their trading on 'noise' are not fully rational. The demands of these investors with regard to risky assets are influenced by thoughts and beliefs that cannot be properly justified by fundamental values. Investor sentiment is commonly defined as a belief about future earnings and investment risks that cannot be confirmed by the facts investors have (Baker and Wurgler, 2007: 129). Overall, studies indicate that unpredictable changes in investor sentiment may affect stock prices (Shleifer and Summers, 1990; De
Long et al., 1990; Baker and Wurgler, 2007; Kaplanski and Levy, 2010). In this context, when sensitivity is high, investors cannot make correct evaluations about the size and risk of future cash flows, and this can lead to an overvaluation of stocks. The exact opposite situation is valid in periods when sensitivity is low (Mian and Sankaraguruswamy, 2012: 1358).

Certain events generating positive or negative sentiment may influence investment decisions and stock prices (Donadelli et al., 2017: 84). Negative sentiment, as well as fear and panic, leads to negative returns (French, 2018; Shu, 2010; Donadelli et al., 2017). There are many studies examining pandemics and their effects on financial markets (Chen et al., 2007; Ali et al., 2010; Chen et al., 2018; Schell et al., 2020). The effects of the COVID-19 on financial markets appear to be similar to those identified in the literature (Albulescu, 2020; Al-Awadhi et al., 2020; Baig et al., 2020; Ashraf, 2020; Cepoi, 2020; Haroon and Rizvi, 2020; Engelhardt et al., 2020; Baker et al., 2020; Salisu and Vo, 2020; He et al., 2020; Liu et al., 2020; Schell et al., 2020). Schell et al. (2020) point out that the COVID-19 pandemic is one

' Dr. Öğr. Üyesi, Trabzon Üniversitesi, Turizm ve Otelcilik MYO, Seyahat-Turizm ve Eğlence Hizmetleri Bölümü, ebulut@trabzon.edu.tr

2 Dr. Ögrr. Üyesi, Trabzon Üniversitesi, Vakfıkebir MYO, Yönetim ve Organizasyon Bölümü, sevalakbulut@trabzon.edu.tr

${ }^{3}$ Dr. Öğr. Üyesi, Trabzon Üniversitesi, Vakfıkebir MYO, Finans-Bankacılık ve Sigortacılık Bölümü, gulayakyuz@trabzon.edu.tr 
of the costliest epidemics in economic terms. Similarly, Baker et al. (2020) evidence that the USA stock market has responded much more influentially to COVID-19 than it has to other pandemics.

During the pandemic period, government restrictions to avoid the spread of the disease have induced unexpected supply-and-demand shocks in some sectors. In response to this, offices and factories have made decisions to reduce costs and ultimately have had to cut back their activities, affecting productivity and profitability (Liu et al., 2020: 16-17). According to early estimates by the ILO, significant increases in unemployment and underemployment which is about from 5.3 million to 24.7 million are expected after the pandemic. It is clear to understand the destructiveness of the economic effects of the pandemic when comparing this expectation with the increase in the unemployment figure by 22 million experienced in the 2008 financial crisis (ILO, 2020). From the losses among airline companies, it can be seen how difficult the sustainability of enterprises is. Air France-KLM's income fell by $15.5 \%$ in the first quarter of 2020 (Reuters, 2020), while the International Airlines Group reported a loss of 2.2 billion euros in the second quarter (Caswell, 2020). During this period, Norwegian Air cancelled 97 Boeing aircraft not yet supplied in fulfilment of the order it had placed with Boeing in 2012 and claimed compensation from the plane-maker (CNBC, 2020). At the same time, the financing problems of credit-dependent companies, degression in investments, and a decrease in innovation and entrepreneurship are important negative outcomes of the pandemic (World Bank, 2020). The decrease in economic activities globally due to the pandemic explains the panic in the financial markets. As is well known, stock prices stand in for earning potential in the future. In this context, the decrease in economic activities affects the earnings expectations of investors, and investors are concerned about future cash flows (Liu et al., 2020: 16-17). In parallel with the increase in the number of COVID-19 cases, the FTSE, Nikkei and Dow Jones Industrial Average have seen large decreases: in fact, Dow and FTSE have seen their biggest decline since the first quarter of 1987 (Jones et al., 2020).

The rapid spread of the COVID-19 pandemic has increased the sensitivity of many people to news, including investors. It can be said that COVID-19 has led to a news flood all over the world, especially due to its human and economic effects. Media coverage of panic and fear related to the pandemic and of the search for a vaccine affects investor sentiment and increases investors' concerns about their future cash flows (Lee, 2020: 1; Baig et al., 2020). A high degree of pessimism in the news predicts downward pressure on market prices (Tetlock, 2007: 1139). On the other hand, there are findings that positive emotions increase the willingness of investors to take risks (Donadelli et al., 2017). Baker and Wurgler (2007) have obtained findings that investor sentiment has significant effects on the stock market. Similarly, Engelhardt et al. (2020) have established that the decrease in stock markets is related to news attention, rather than to rational expectation. Haroon and Rizvi (2020) revealed that panic created by COVID-19-related media coverage has effects on financial markets.

This study is motivated by the need to investigate how negative events may affect the sensitivity of investors. It aims to test the effect of COVID-19-related news-based investor sentiment on BIST100 Index returns. It demonstrates originality by using COVID-19-related news-based investor sentiment proxies and examining the capital market in terms of behavioural finance for the period of the pandemic. In this context, this study followed Tetlock's (2007) study, which found that media content and stock market activity are correlated. In particular, the study investigates the effect of investor sentiment induced by a specific event of the COVID-19 pandemic. In this framework, after the introduction, the theoretical background on investor sentiment and stock markets is introduced. Then, a literature review on COVID-19-related investor sentiment and its relationship to stock returns are presented. The fourth section discusses the measurement of investor sentiment, while the data and methodology are explained in the fifth section. The sixth section introduces the research findings, which are then evaluated in the last section.

\section{MOTIVATION AND BACKGROUND}

An efficient market assumes that participants receive all available information in the market (Fama, 1995: 76). In this context, it is assumed that investors act rationally. However, it has been observed that investors do not act rationally (Baker and Wurgler, 2007: 129). De Long et al. (1990) confirm that irrational noise traders affect prices and claim that the unpredictable beliefs of noise traders and the effect on the market of their expectations increase the risk in the market. In this case, prices may deviate from the fundamental values even when there is no fundamental risk. Shleifer and 
Summers (1990) state that investor sentiment affects their demands, and that arbitrage is risky and limited. The researchers established that limited arbitrage is more reasonable than perfect arbitrage by revealing that investor sentiment is an important determinant of prices. Similarly, Shleifer and Vishny (1997) confirmed the assumption of behavioural finance that arbitrage is limited. Shu (2010) evaluates the mood of investors as a very important factor for equilibrium asset prices and returns. Bathia and Bredin (2013) found that with respect to high investor sentiment, future returns are low. Conversely, low investor sentiment is related to high future returns. According to Shu (2010), the mental or psychological conditions of investors can influence their choices, risk assessments and attendant investment decisions. Therefore, financial decisions can be expected to vary according to the mood of investors (Shu, 2010: 267).

It is possible to say that certain events can create a particularly positive or negative emotion affecting the relevant stock market prices - that is, they can affect investor sentiment (Donadelli et al., 2017: 84). As Kahneman and Tversky' (1979) prospect theory which forms the basis of behavioural finance, losses outweigh gains for investors. De Bondt and Thaler (1985) associate the overreaction of investors with psychological findings and attribute price anomalies to the overreaction of investors to unexpected and dramatic events. In such cases, particularly adverse events can be expected to have a large effect on investor sentiment, and in particular, negative events have a higher impact than positive events on investor sentiment (Baker and Wurgler, 2007: 129-130). Baker and Wurgler (2007) state that investor sentiment and emotional waves have significant effects on stock market. Investor sentiment theory assumes that short-run returns will reverse in the long run. However, information theory assumes that short-term returns will not change in the long run (Tetlock, 2007: 1143). Unlike previous studies, Verma et al. (2008) obtained findings that individual and institutional investor sentiment can be both fundamental-driven (rational) and irrational.

\section{LITERATURE REVIEW: COVID-19- RELATED INVESTOR SENTIMENT AND ITS RELATIONSHIP TO STOCK RETURNS}

COVID-19 appeared first in China, spread rapidly all over the world and became a pandemic. Due to the measures taken in response to this rapid spread, the pandemic has had very unfavourable effects on the economies and financial markets. During this stage, the ever-increasing cases and death rates have triggered an increase in fear and panic among the people. The reflection of this panic and uncertainty on financial markets in different countries have been an important research topic. Albulescu (2020) investigated the relationship between COVID-19 cases and death rates and the financial market volatility index, and found that mortality rates positively affect the volatility index, especially in countries other than China. In addition, he points out that volatility increases as the number of countries is affected by COVID-19 increases. Similarly, Al-Awadhi et al. (2020) have determined that the daily increase in total cases and total deaths in China had significant negative effects on the stock returns of all companies.

Investigating the COVID-19 outbreak and the microstructure of US stock market relationships, Baig et al. (2020) found that an increase in liquidity and volatility dynamics is associated with an increase in confirmed cases and deaths due to COVID-19. According to Baig et al. (2020), government restrictions, lockdowns and a declining level of sentiment worsen the stability and liquidity of the markets. Similarly, Ashraf (2020) has determined that stock markets have reacted negatively to the increase in confirmed COVID-19 cases. According to Ashraf (2020), stock markets have responded rapidly to the COVID-19 pandemic, and this response has changed over time depending on the stage of the pandemic reached.

Disaster-related news and media coverage are also factors that trigger fear and panic. This fear and panic affects the expectations of investors. As is known from the finance literature, investor sentiment effects stock returns significantly (De Long et al., 1990; Baker and Wurgler, 2006, 2007; Shleifer and Vishny, 1997; Shu, 2010: 267; Donadelli et al., 2017). Tetlock (2007) states that high pessimism in the media indicate a change in the stock price due to downward pressure. He also finds that uncommonly high or low pessimism in the media predict high market volatility. According to Tetlock's (2007) findings, movements in market prices and trading volume can be predicted by the content of the news in the media.

Cepoi (2020) analysed the effect of COVID-19-related news on stock market returns in the USA, the UK, France, Germany, Italy and Spain for the period 3 February 2020 - 17 April 2020. According to Cepoi (2020), the findings show that it is important to use proper communication channels to reduce the confusion caused by the COVID-19 pandemic in financial markets. 
Similarly, Haroon and Rizvi (2020) examined the relationship between the sentiment caused by the news on COVID-19 and the volatility of stock markets for the period 1 January 2020 - 30 April 2020. The researchers used the benchmark indices for the world and the USA, and 23 sectoral indices for the USA from Dow Jones. They found that news-induced panic and increasing volatility in stock markets are related. In addition, they observe that panic related news caused more volatility in the stocks of the sectors that are thought to be most affected by the pandemic.

Lee (2020) analysed the first effect of COVID-19 sentiment on the US stock market. Lee (2020) analysed investor sentiment through Google Trends data on coronavirus-related searches and the Daily News Sentiment Index (DNSI) and found that the effects of COVID-19 sentiment vary between 11 industry indices for the period 21 January 2020 - 20 May 2020. Engelhardt et al. (2020) analysed whether the decrease in stock market performance during to COVID-19 was due to news interest or to the rational expectations of investors, coupled with the economic impact of the pandemic. The researchers used data from 64 countries comprising $94 \%$ of world GDP for the period between 22 January 2020 and 9 April 2020. They found that the decrease in stock markets is related less to rational expectation and more to news attention. According to Engelhardt et al. (2020), the economic effect of media hype will be excessive for the USA and the rest of the G8 countries.

Baker et al. (2020) analysed the effects of pandemics on the stock market using text-based methods, through both automated and human readings of newspaper articles. The researchers found that the stock market has responded to the COVID-19 pandemic much more strongly than to previous pandemics. According to Baker et al. (2020), the measures taken by the government are important reasons for the dramatic effects on the stock markets. Similarly, Schell et al. (2020) studied the response of 26 stock market indices to disease-related news announcements made by the World Health Organization on H1N1 (swine influenza) in 2009, the poliovirus and Ebola outbreaks in West Africa in 2014, the Zika virus in 2016, the Ebola outbreak in 2019, and COVID-19 in 2020. They conclude that diseases other than COVID-19 had a relatively low economic impact on a global scale. Schell et al. (2020) also found that only COVID-19 affected stock markets negatively for at least 30 days. Salisu and Vo (2020) analysed the relationship between health news trends obtained through Google
Trends for 20 countries during the COVID-19 pandemic and the predictability of stock returns for the period 1 January 2020 - 30 March 2020. They determined that health news searches predict stock returns well since the emergence of the pandemic.

He et al. (2020) examined the market performance and response trends of Chinese industries in relation to COVID-19. They considered 2895 companies registered on Shanghai and Shenzhen stock exchanges using the case study approach for the period 3 June 2019- 13 March 2020. They found that the pandemic has positively affected the stock prices in the Shenzhen Stock Exchange, but that it has had a negative impact on the stock prices in the Shanghai Stock Exchange. Similarly, Liu et al. (2020) analysed the short-term effects of the coronavirus epidemic on 21 leading stock market indices in the major countries over two periods - a pre-event period from 21 February 2019 to 19 January 2020 and a post-event period from 20 January 2020 to 18 March 2020. Their findings show that stock markets fell rapidly after the pandemic in the major countries and regions.

\section{MEASUREMENT OF INVESTOR SENTIMENT}

As is known from the finance literature, market-based metrics, confidence and sentiment surveys, internet search queries and news are used as proxies for investor sentiment. Baker and Wurgler $(2006,2007)$ combine six distinct proxies to create an index. Their sentiment index based on trading volume is measured by the closed-end fund discount, NYSE turnover, the number of and first-day returns on IPOs, the dividend premium, and the equity share in new issues. Similarly, Smales (2017) uses the composite index created by Baker and Wurgler (2006) as an investor sentiment proxy, in addition to other sentiment proxies. Baker and Stein (2004) and Tas and Sen (2019) use trading volume as a proxy for investor sentiment, while Kandır et al. (2013) use a consumer confidence index and the closed-end fund discount.

According to Da et al. (2015), market-based investor sentiment measures provide the convenience of obtaining data at a relatively high frequency. However, these measures have the disadvantage of carrying the effects of many economic factors in addition to investor sentiment. Hence, Da et al. (2015) created the Financial and Economic Attitudes Revealed by Search (FEARS) index by using internet search queries. According to Da et al. (2015), investor sentiment can be measured 
through the internet search behaviour of households. Similarly, Salisu and Vo (2020) and Oliveira-Brochado (2019) use a Google search-based sentiment index. On the other hand, Bollen et al. (2011) measure sentiment utilizing Twitter feeds, while Kaplanski and Levy (2014) analyse football results as a sentiment proxy. According to Lee (2020), sentiment analysis, which uses big data drawn from social media, is a good source of information during times when the stock markets face a sudden and unpredictable event like the COVID-19 pandemic. Lee (2020) states that these analyses can provide forecasts to investors that determine investment strategies. On the other hand, investors find it difficult to properly evaluate the economic significance and effect of such information when they have extensive access to news and information (Haroon and Rizvi, 2020: 1). According to Li (2018), while positive news improves stock market performance and the trading of individual stocks, negative news impedes it. Besides, media coverage of disasters increases anxiety and fear and causes sensitivity among investors (Kaplanski and Levy, 2010). Donadelli et al. (2020) examine the fear index as a sentiment proxy, consistent with the common view that disease-related news can cause panic, fear and anxiety among investors. Haroon and Rizvi (2020) examine the panic index, sentiment index and media coverage index which are created from COVID-19 pandemic-related news, and they have analysed the sentiment arising from the media. Similarly, Cepoi (2020) examines the panic index, the media hype index, the fake news index, the country sentiment index, the contagion index and the media coverage index. Tetlock (2007) establishes in his findings that media content metrics act as a proxy for investor sentiment. Similarly, the present study examines media-coverage-based measures as an investor sentiment proxy.

\section{DATA AND METHODOLOGY}

The effect of investor sentiment on the Borsa Istanbul 100 Index is examined in this study for the period 11 March 2020 - 19 August 2020 through the news on the COVID-19 pandemic. Following Cepoi (2020) and Haroon and Rizvi (2020), the news index values for Turkey which are obtained through the coronavirus news monitor launched by RavenPack and given in Table 1 are used.

ADF (Augmented Dickey Fuller) and Fourier ADF unit root tests (Dickey and Fuller, 1981) were used to establish the stationarity levels of the variables. The Dolado-Lütkepohl (1996) (DL) causality test and the ARDL (autoregressive distributed lag) method developed by Pesaran (Pesaran et al., 2001) were used to investigate the effects of panic, fear, media coverage and discussion of a vaccine - indices for which were created by taking into account the news on the COVID-19 pandemic - on the BIST100 Index return. The cross-correlation method was used for graphical analysis.

Trigonometric terms are used in the equations, unlike the ADF test in the Fourier ADF unit root test developed by Christopoulos and León-Ledesma (2010). Fourier series are defined in the Fourier ADF test as the

Table 1: The Data

\begin{tabular}{|c|c|c|}
\hline Variables & Description and source & Source \\
\hline $\begin{array}{l}\text { Stock Market } \\
\text { Return } \\
\text { (BIST100) }\end{array}$ & Daily rate of change, the Borsa lstanbul 100 return & $\begin{array}{l}\text { Borsa Istanbul Data } \\
\text { Platform }\end{array}$ \\
\hline $\begin{array}{l}\text { Panic Index } \\
\text { (PI) }\end{array}$ & $\begin{array}{l}\text { This measures the proportion of media coverage referring to panic or hysteria } \\
\text { and the coronavirus. Index values range from } 0 \text { to } 100: \text { a higher value indicates a } \\
\text { greater number of references to panic and COVID-19. }\end{array}$ & \multirow{4}{*}{$\begin{array}{l}\text { RavenPack https:// } \\
\text { coronavirus.ravenpack.com }\end{array}$} \\
\hline Fear (F) & $\begin{array}{l}\text { This measures how frequently the theme of fear appears alongside mentions of } \\
\text { the coronavirus, expressed as a percentage of all news stories about the virus. }\end{array}$ & \\
\hline $\begin{array}{l}\text { Media } \\
\text { Coverage } \\
\text { Index (MCl) }\end{array}$ & $\begin{array}{l}\text { This measures how frequently the topic of the novel coronavirus is covered } \\
\text { among all news sources. Index values range from } 0 \text { to } 100 \text {, so e.g. a value of } \\
60.00 \text { means that currently } 60 \% \text { of all stories among sampled news providers } \\
\text { relate to COVID- } 19 \text {. }\end{array}$ & \\
\hline Vaccine (V) & $\begin{array}{l}\text { This measures how frequently the subject of a vaccine appears alongside } \\
\text { mentions of the coronavirus, expressed as a percentage of all news stories about } \\
\text { the virus. }\end{array}$ & \\
\hline
\end{tabular}

Note: Variables are used in the analysis by taking their logarithms. 
sum of cosines and sines (trigonometric values) of the periodic $y_{-} t$ function, as shown in Equation (1).

$$
y_{t}=\delta_{0}+\delta_{1} \sin \left(\frac{2 \pi k t}{T}\right)+\delta_{2} \cos \left(\frac{2 \pi k t}{T}\right)+v_{t}
$$

In Equation (1), $t$ refers to trend, $T$ refers to sample size, $\pi=3.1416$ and $k$ refers to the frequency value, taking an integer value between 1 and 5 , which minimizes the sum of residual squares. The optimal frequency number of $k$ is specified by estimating Equation (1), and the residues are obtained as in Equation (2).

$$
v_{t}=y_{t}-\left[\delta_{0}+\delta_{1} \sin \left(\frac{2 \pi k t}{T}\right)+\delta_{2} \cos \left(\frac{2 \pi k t}{T}\right)\right]
$$

In order to apply the standard ADF unit root test to the residues that are calculated with the help of Equation (2), Equation (3) is estimated.

$$
\Delta v_{t}=\alpha_{1} v_{t-1}+\sum_{i=1}^{p} \beta_{j} \Delta v_{t-j}+\varepsilon_{t}
$$

In Equation (3), the null hypothesis shows the unit root process as $(H 0=a 1=0)$, while the alternative hypothesis shows the stationarity as $(H 1=a 1<0)$ in linear form for the Fourier ADF test (Destek and Okumuş, 2016: 78). The calculated test statistic is compared with the critical values created according to the number of $k$ frequencies determined by the Fourier ADF test in Christopoulos and León-Ledesma's work (2010: 1083), and a decision is made about the stationarity.

If the variables are stationary, the significance of the trigonometric terms (calculated $\mathrm{F}(k)$ test) in Equation (1) will be compared with the critical values in the study of Becker et al. (2006: 389). It is recommended to use the Fourier ADF test if the trigonometric terms are significant and the standard ADF test if the trigonometric terms are insignificant (Enders and Lee, 2012: 196-197).

\subsection{Dolado-Lütkepohl (DL) Causality Method}

The optimal lag length $k$ is determined in the first place using the Dolado-Lütkepohl causality method with the help of the VAR (vector autoregression) model according to the criteria LR, FPE, AIC, SIC and $\mathrm{HQ}$. By adding $a+1$ lag to the determined optimal lag length, the VAR $(k+1)$ model is estimated. To determine whether the estimated VAR model is smooth and stable, tests such as AR unit root, autocorrelation, heteroscedasticity and normality tests (diagnostic tests) are performed. In the next phase, the Wald test is applied to the $k$ lag coefficient matrix of the independent variables in Equations (4) and (5) for the VAR $(k+1)$ model that is created to test the causality relationship between two variables such as $X$ and $Y$.

With the help of the DL causality test, in the analysis of the causality relationship between two variables, such as $X$ and $Y$, Equations (4) and (5) are formed.

$$
\begin{aligned}
& \mathrm{X}_{\mathrm{t}}=\varphi_{0}+\sum_{\mathrm{i}=1}^{\mathrm{k}+1} \delta_{\mathrm{i}} \mathrm{X}_{\mathrm{t}-\mathrm{i}}+\sum_{\mathrm{j}=1}^{\mathrm{k}+1} \alpha_{\mathrm{j}} \mathrm{Y}_{\mathrm{t}-\mathrm{j}}+\mathrm{u}_{1 \mathrm{t}} \\
& \mathrm{Y}_{\mathrm{t}}=\gamma_{0}+\sum_{\mathrm{i}=1}^{\mathrm{k}+1} \pi_{\mathrm{i}} \mathrm{Y}_{\mathrm{t}-\mathrm{i}}+\sum_{\mathrm{j}=1}^{\mathrm{k}+1} \beta_{\mathrm{j}} \mathrm{X}_{\mathrm{t}-\mathrm{j}}+\mathrm{u}_{2 \mathrm{t}}
\end{aligned}
$$

As a result of the Wald test applied to the lag coefficient matrix $k$ in the VAR $(k+1)$ model, it is concluded that there is a one-way causality relationship from $Y$ to $X$ if $\alpha j \neq 0$ in Equation (4); and from $X$ to $Y$ if $\beta j \neq 0$ in Equation (5). If $\alpha j \neq 0$ and $\beta j \neq 0$ together, it is assumed that there is a two-way causality relationship between variables.

\subsection{ARDL Method}

A boundary test is made to determine the cointegration relationship between two variables such as $X$ and $Y$ using the ARDL method. The unrestricted error correction model in the estimation of the F statistic that will be used for the boundary test is defined as in Equation (6).

$$
\Delta \mathrm{Y}_{\mathrm{t}=} \beta_{0}+\sum_{\mathrm{i}=1}^{\mathrm{m}} \beta_{\mathrm{i}} \Delta \mathrm{Y}_{\mathrm{t}-\mathrm{i}}+\sum_{\mathrm{i}=0}^{\mathrm{n}} \delta_{\mathrm{i}} \Delta \mathrm{X}_{\mathrm{t}-\mathrm{i}}+\mu_{\mathrm{i}} \mathrm{Y}_{\mathrm{t}-1}+\sigma_{\mathrm{i}} \mathrm{X}_{\mathrm{t}-1}+\mathrm{u}_{\mathrm{t}}
$$

In Equation (6), $m$ and $n$ refer to optimal lag lengths and $\Delta$ refers to first-degree differences. It is stated that if zero and alternative hypotheses are $\mathrm{H}_{0}: \mu_{i}=\sigma_{\mathrm{i}}=0$ in Equation (6), which is estimated for the $\mathrm{F}$ statistic to be used in the ARDL boundary test, there is no cointegration relationship between the series; and if $\mathrm{H}_{1}: \mu_{i} \neq \sigma_{\mathrm{i}} \neq 0$, there is a cointegration relationship between the series.

As a result of the boundary test, the long- and shortterm relationships between the variables for which a cointegration relationship is determined are examined. The long-term ARDL $(m, n)$ model is estimated as in Equation (7), after the lag lengths of the dependent ( $Y$ ) and the independent $(X)$ variables are determined according to the AIC.

$$
\mathrm{Y}_{\mathrm{t}=} \beta_{0}+\sum_{\mathrm{i}=1}^{\mathrm{m}} \beta_{2 \mathrm{i}} \mathrm{Y}_{\mathrm{t}-\mathrm{i}}+\sum_{\mathrm{i}=0}^{\mathrm{n}} \beta_{3 \mathrm{i}} \mathrm{X}_{\mathrm{t}-\mathrm{i}}+\mathrm{u}_{\mathrm{t}}
$$

The error correction model of the ARDL $(m, n)$ model is formed in order to determine the short-term relationship between variables, as in Equation (8).

$\Delta \mathrm{LY}_{\mathrm{t}}=\alpha_{0}+\sum_{\mathrm{i}=1}^{\mathrm{m}} \omega_{\mathrm{i}} \Delta \mathrm{LY}_{\mathrm{t}-\mathrm{i}}+\sum_{\mathrm{i}=1}^{\mathrm{n}} \varphi_{\mathrm{i}} \Delta \mathrm{LX}_{\mathrm{t}-\mathrm{i}}+\tau \mathrm{ECT}_{\mathrm{t}-1}+\mathrm{u}_{\mathrm{t}}(8)$ 
The coefficients in Equation (8) show the short-term coefficients of the model. $\mathrm{ECT}_{\mathrm{t}-1}$ is the error correction term. It is expected that the coefficient of $\tau$ for the error correction term will be negative and significant. If the $\tau$ coefficient is between 0 and -1 , this indicates that it stabilizes in the long term. Besides, Narayan and Smyth (2006: 339) argue that if this coefficient is greater than $-1(\tau>-1)$ it will fluctuate and stabilize in the long term.

\subsection{Cross-correlation Function}

In the cross-correlation function, correlation coefficients are calculated, and analysis is performed by obtaining information about the direction of the relationship between these coefficients and the variables. The measurement of a linear relationship or association between variables is identified as a positive value, while the measurement of an opposite relationship or association is a negative value. If there is no association between the two variables, they are statistically independent (Sevüktekin and Nargeleçekenler, 2010: 243).

The correlation coefficient is the measure of the association between a standard deviation change in $X$ (independent variable) and a standard deviation change in $Y$ (dependent variable). Hence, the correlation coefficient is equal to the division of the products of the standard deviations of $X$ and $Y$ to $\operatorname{Cov}(X, Y)$. In short, it is formulated as in Equation (9) (Sevüktekin and Nargeleçekenler, 2010:246).

$$
\tilde{\mathrm{n}}(\mathrm{X}, \mathrm{Y})=\frac{\operatorname{Cov}(\mathrm{X}, \mathrm{Y})}{\sqrt{\operatorname{Var}(\mathrm{X})} \sqrt{\operatorname{Var}(\mathrm{Y})}}=\frac{\operatorname{Cov}(\mathrm{X}, \mathrm{Y})}{{ }^{\mathrm{o}} \mathrm{X}^{\mathrm{o}} \mathrm{Y}}
$$

The covariance between two variables such as $\mathrm{X}$ and $Y$ in this definition is calculated as in Equation (10) (Sevüktekin and Nargeleçekenler, 2010: 246).

$$
\operatorname{Cov}(X, Y)=\sum_{i=1}^{N}\left(X_{i}-\bar{X}\right)\left(Y_{i}-\bar{Y}\right)
$$

$\sigma_{x}$ and $\sigma_{y}$ are the standard deviations of $X$ and $Y$ respectively:

$$
\hat{o} \mathrm{X}=\sqrt{\frac{\sum\left(\mathrm{X}_{\mathrm{i}}-\overline{\mathrm{X}}\right)^{2}}{\mathrm{~N}-1}}
$$

and

$$
\text { ó } \mathrm{Y}=\sqrt{\frac{\sum\left(\mathrm{Y}_{\mathrm{i}}-\overline{\mathrm{Y}}\right)^{2}}{\mathrm{~N}-1}}
$$

are calculated as above. Equations (10), (11) and (12) can be reformed as in Equation (13) below by replacing the correlation coefficient in Equation (9) (Sevüktekin and Nargeleçekenler, 2010: 247):

$$
\rho_{X Y}=\frac{\sum_{i=1}^{N}\left(X_{i}-\bar{X}\right)\left(Y_{i}-\bar{Y}\right)}{\sqrt{\sum_{i=1}^{N}\left(X_{i}-\bar{X}\right)^{2}\left(Y_{i}-\bar{Y}\right)^{2}}}
$$

Cross-correlation coefficients between variables for the past and future periods are also calculated using Equation (13). Therefore, in order to analyse the relationship in the cross-correlation function that is used to find out the dynamic relationship between variables, cross-correlation coefficients must be calculated. Accordingly, when the cross-correlation coefficients between $X$ (independent variable) and $Y$ (dependent variable) are reformed according to Equation (14), $(\rho X, Y(k))$ will be calculated as in Equation (14).

$$
\rho_{\mathrm{X}, \mathrm{Y}}(\mathrm{k})=\frac{\sum\left[\left(\mathrm{X}_{\mathrm{t}+\mathrm{k}}-\overline{\mathrm{X}}\right)\left(\mathrm{Y}_{\mathrm{t}}-\overline{\mathrm{Y}}\right)\right]}{\sqrt{\sum\left(\mathrm{X}_{\mathrm{t}+\mathrm{k}}-\overline{\mathrm{X}}\right)^{2} \Sigma\left(\mathrm{Y}_{\mathrm{t}}-\overline{\mathrm{Y}}\right)^{2}}}
$$

In Equation (14), $X_{t+k}$ represents current, future and past $t$-period values of the dependent variable; and $Y_{t}$ represents the t-period value of the dependent variable. $\bar{X}$ and $\bar{Y}$ represent the means of independent and dependent variables. $k$ represents the lag and lead length.

In the aforementioned equation, the instant correlation between $X$ and $Y$ is obtained when $k=0$; and cross-correlation between $X_{t \pm 1}$ and $Y_{t}$ is obtained when $k= \pm 1$. Future periods where $k$ is positive give the cross-correlation that shows leading effects, while past periods where $k$ is negative give the cross-correlation that shows lagged effects. Thus, instant correlations between independent and dependent variables, as well as cross-correlations that reveal lagged and leading effects, can be calculated with this method. A unique $\rho$ value is calculated in the analysis for each $k$ value. The cross-correlation function graph between $X_{t \pm k}$ and $Y_{t}$ is obtained with the graph drawn through the cross-correlation function with $\rho$ values (cross-correlation coefficients) on the vertical axis and $k$ values (current, lead and lag length values) on the horizontal axis.

With the graphs obtained, the effects of current, lead and lag values of the panic, vaccine, fake news, fear, media hype, media coverage and contagion indices on the BIST100 return will be analysed visually and the robustness of the findings will be evaluated. 


\section{RESEARCH FINDINGS}

The results of the BIST100 index value and the ADF and Fourier ADF unit root tests of the variables $\mathrm{PI}, \mathrm{F}, \mathrm{MCl}$ and $V$ are given respectively in Tables 2 and 3.

If the absolute values of $t$ statistics that are calculated with the help of the ADF test are greater than (less than) the critical absolute values of the table, it is decided that the series is stationary (not stationary). When we look at the results in Table 2, the BIST100 variable is stationary at the 1 st difference, according to the ADF unit root test, while other variables are stationary at the level.

Table 2: ADF Unit Root Test

\begin{tabular}{|c|c|c|c|c|}
\hline \multirow[b]{2}{*}{ Variables } & \multicolumn{2}{|l|}{ At level } & \multicolumn{2}{|c|}{ At 1st difference } \\
\hline & Constant & $\begin{array}{l}\text { Constant + } \\
\text { trend }\end{array}$ & Constant & $\begin{array}{l}\text { Constant + } \\
\text { trend }\end{array}$ \\
\hline BIST100 & $-2.37(0.15)$ & $-3.07(0.11)$ & $-8.84(0.00)^{a}$ & $-8.97(0.00)^{a}$ \\
\hline PI & $-4.00(0.00)^{a}$ & $-10.92(0.00)^{a}$ & $-5.69(0.00)$ & $-5.66(0.00)$ \\
\hline $\mathbf{F}$ & $-7.38(0.00)^{a}$ & $-8.26(0.00)^{a}$ & $-7.49(0.00)$ & $-7.45(0.00)$ \\
\hline MCI & $-1.38(0.58)$ & $-6.41(0.00)^{a}$ & $-8.13(0.00)^{a}$ & $-8.12(0.00)^{a}$ \\
\hline $\mathbf{v}$ & $-9.87(0.00)^{a}$ & $-9.83(0.00)^{a}$ & $-7.38(0.00)$ & $-7.34(0.00)$ \\
\hline
\end{tabular}

Note: Values in ( ) represent the $p$ value of $t$ statistics. Table critical values in the constant model are 1\%: $-3.50,5 \%:-2.89,10 \%:-2.58$; in the constant and trend model, $1 \%:-4.05,5 \%:-3.45,10 \%:-3.15$. a: significant at the $1 \%$ level, b: significant at the $5 \%$ level.
Table 3: Fourier ADF Unit Root Test Results

\begin{tabular}{lllll}
\hline Variables & Min. KKT & $k$ & FADF & $\mathrm{F}(k)$ \\
\hline BIST100 & 2.049 & 1 & -2.576 & 3.029 \\
\hline $\mathbf{P I}$ & 5.744 & 1 & $\mathbf{- 1 0 . 8 7 1 ^ { a }}$ & $\mathbf{1 0 . 1 4 2}^{\mathbf{a}}$ \\
\hline $\mathbf{F}$ & 3.96 & 2 & $\mathbf{- 8 . 2 3 3 ^ { a }}$ & $\mathbf{6 . 8 8 6}^{a}$ \\
\hline $\mathbf{M C I}$ & 0.214 & 1 & $\mathbf{- 7 . 3 6 1 ^ { a }}$ & $\mathbf{1 7 . 1 9 1}^{a}$ \\
\hline $\mathbf{V}$ & 3.054 & 4 & $-10.379^{a}$ & $10.684^{a}$ \\
\hline
\end{tabular}

Note: $\mathrm{k}$ represents the frequency number. Table critical values for $k=1$ are $1 \%:-4.43,5 \%:-3.85,10 \%:-3.52$; table critical values for $k=2$ are $1 \%:-3.95,5 \%:-3.28,10 \%:-2.91$; table critical values for $k=4$ are $1 \%:-3.60,5 \%:-2.93,10 \%:-2.59$. Table critical values for the significance of trigonometric terms are $1 \%: 6.73,5 \%: 4.92,10 \%$ : 4.13. a: significant at the $1 \%$ level; b: significant at the $5 \%$ level, c: significant at the $10 \%$ level. $\Delta$ represents difference operator.

According to the result of the Fourier ADF test as seen in Table 3, other variables - except the BIST100 variable - are stationary at the level under structural change. Since the F $(k)$ statistic of the BIST100 variable is insignificant, it is decided that the finding obtained from the ADF test is appropriate to decide on the stationarity of this variable (Enders and Lee, 2012: 196-197).

As a result of unit root tests, while the BIST100 variable is stationary at the 1 st difference I(1), other variables are stationary at the level I(0). The Dolado-Lütkepohl causality and ARDL methods have been chosen in the analysis of the relationship between BIST100 (dependent variable), which has different levels of stability, and the variables of $\mathrm{PI}, \mathrm{F}, \mathrm{MCl}$, and $\mathrm{V}$ (independent variable).

The results of DL causality analysis are given in Table 4.

Table 4: DL Causality Test Results

\begin{tabular}{|c|c|c|c|c|c|c|c|}
\hline $\begin{array}{l}\text { VAR } \\
\text { Model }\end{array}$ & $k+1$ & $\begin{array}{l}\text { Wald ist. } \\
\text { (P value) }\end{array}$ & Causality & $\begin{array}{l}\text { LM } \\
(\mathrm{P} \\
\text { value })\end{array}$ & $\begin{array}{l}\text { White } \\
\text { (P } \\
\text { value) }\end{array}$ & $\begin{array}{l}\text { Inverse roots of the } \\
\text { AR characteristic } \\
\text { polynomial } \\
\text { (maximum value) }\end{array}$ & $\begin{array}{l}\text { Findings } \\
\text { summary }\end{array}$ \\
\hline $\begin{array}{l}B I S T 100=f(P I) \\
P I=f(B I S T 100)\end{array}$ & $1+1$ & $\begin{array}{l}\mathbf{3 1 . 3 5}(\mathbf{0 . 0 0})^{\mathrm{a}} \\
1.02(0.31)\end{array}$ & $\begin{array}{l}\mathrm{PI} \rightarrow \text { BIST100(-0.68) } \\
\text { No causality }\end{array}$ & $\begin{array}{l}5.03 \\
(0.28)\end{array}$ & $\begin{array}{l}63.84 \\
(0.34)\end{array}$ & 0.66 & $\begin{array}{l}\text { One-way } \\
\text { negative } \\
\text { causality }\end{array}$ \\
\hline $\begin{array}{l}B I S T 100=f(F) \\
F=f(B I S T 100)\end{array}$ & $1+1$ & 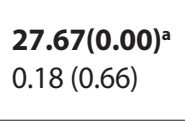 & $\begin{array}{l}\text { F } \rightarrow \text { BIST100(-0.72) } \\
\text { No causality }\end{array}$ & $\begin{array}{l}0.29 \\
(0.99)\end{array}$ & $\begin{array}{l}35.22 \\
(0.91)\end{array}$ & 0.66 & $\begin{array}{l}\text { One-way } \\
\text { negative } \\
\text { causality }\end{array}$ \\
\hline $\begin{array}{l}B I S T 100=f(M C I) \\
M C I=f(B I S T 100)\end{array}$ & $5+1$ & $\begin{array}{l}10.24(0.06)^{b} \\
9.12(0.11)\end{array}$ & $\begin{array}{l}\text { MCI } \rightarrow \text { BIST100(-0.29) } \\
\text { No causality }\end{array}$ & $\begin{array}{l}6.39 \\
(0.17)\end{array}$ & $\begin{array}{l}53.11 \\
(0.95)\end{array}$ & 0.22 & $\begin{array}{l}\text { One-way } \\
\text { negative } \\
\text { causality }\end{array}$ \\
\hline $\begin{array}{l}\text { BIST100 = f(V) } \\
V=f(B I S T 100)\end{array}$ & $1+1$ & 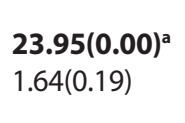 & $\begin{array}{l}\mathbf{V} \rightarrow \text { BIST100(+0.38) } \\
\text { No causality }\end{array}$ & $\begin{array}{l}3.73 \\
(0.43)\end{array}$ & $\begin{array}{l}63.18 \\
(0.36)\end{array}$ & 0.65 & $\begin{array}{l}\text { One-way } \\
\text { positive } \\
\text { causality }\end{array}$ \\
\hline
\end{tabular}

Note: $k$ represents the optimal lag length. a: significant at the $1 \%$ level, b: significant at the $5 \%$ level. 
According to the results of the analysis in Table 4, a one-way negative and statistically significant causality relationship has been found between the BIST100 variable and the $\mathrm{PI}, \mathrm{F}$ and $\mathrm{MCl}$ variables. Table 4 also shows that there is a one-way positive and statistically significant causality relationship between the vaccine index and the BIST100 return. It is concluded that the panic, fear and media coverage indices affect the BIST100 return negatively, and the vaccine index affects the BIST100 return positively. It has been established that there is no problem in the diagnostic tests of VAR models (the probability values of White variance, LM autocorrelation and JB normal distribution tests are greater than 0.10), and the inverse roots of the $A R$ characteristic polynomial that belong to the models are less than 1. In Table 4, it can be seen that the estimated models are reliable, problem-free and stable.

Findings obtained from DL causality analysis prove that media content is an indicator of stock markets, as stated in the determinations of Tetlock (2007). In addition, investor sentiment cannot be observed directly and its effects on the markets are analysed using proper proxies, as emphasized by Smales (2017). Within this framework, the fact that news indices, which are considered proxies for investor sentiment, have an effect on returns indicates that returns have been affected by investor sentiment during the COVID-19 pandemic. To verify this indicator, the short- and long-term relationship needs to be analysed. As Tetlock's (2007) findings confirm, a high level of media pessimism is connected with low investor sentiment, and this pre- dicts a downward pressure on returns. The opposite of this relationship is expected in the long term. In this context, the short- and long-term relationship of investor sentiment to the BIST100 Index value has been analysed using the ARDL boundary test approach, and subsequently, the cross-correlation relationship has been examined to check the robustness of the results.

The results of $F$ statistics calculated to decide whether there is a cointegration relationship between variables using the ARDL method are shown in Table 5.

Table 5: ARDL Bound Test Results

\begin{tabular}{llll}
\hline Model & $k$ & F statistics \\
\hline BIST100 $=f(P I)$ & 1 & $50.96^{a}$ & \\
\hline BIST100 $=f(F)$ & 1 & $26.56^{a}$ & \\
\hline BIST100 $=f(M C I)$ & 1 & $47.60^{a}$ & \\
\hline BIST100 $=f(V)$ & 1 & $11.87^{a}$ & \\
\hline Table critical values & Lower bound I(0) & Upper bound I(1) \\
\hline $10 \%$ & 3.02 & 3.51 \\
\hline $5 \%$ & 3.62 & 4.16 \\
\hline $1 \%$ & 4.94 & 5.58 \\
\hline
\end{tabular}

Note: a: significant at the $1 \%$ level; $\mathrm{k}$ refers to the number of independent variables.

It is concluded in Table 5 that the calculated F statistics values of the models are greater than the table critical values and there is a cointegration relationship between variables. The optimal ARDL models determined to analyse the short- and long-term relationships

Table 6: Long-Term Coefficient

\begin{tabular}{|c|c|c|c|c|c|c|c|}
\hline \multirow{2}{*}{$\begin{array}{l}\text { BIST100 = f(PI) } \\
\operatorname{ARDL}(1,2)\end{array}$} & & \multicolumn{2}{|c|}{ BIST100 = f(MCI) } & \multicolumn{2}{|c|}{ BIST100 = f(F) } & \multicolumn{2}{|c|}{ BIST100 = $f(V)$} \\
\hline & & ARDL & & $A R$ & & $\mathrm{ARL}$ & \\
\hline$P I$ & $\begin{array}{l}-0.03 \\
(-0.55) \\
{[0.57]}\end{array}$ & $\mathrm{MCI}$ & $\begin{array}{l}-0.28^{b} \\
(-2.26) \\
{[0.02]}\end{array}$ & $\boldsymbol{F}$ & $\begin{array}{l}-0.06 \\
(-0.92) \\
{[0.35]}\end{array}$ & $\boldsymbol{V}$ & $\begin{array}{l}0.16^{b} \\
(1.98) \\
{[0.04]}\end{array}$ \\
\hline$C$ & $\begin{array}{l}1.02^{\mathrm{a}} \\
(20.41) \\
{[0.00]}\end{array}$ & $C$ & $\begin{array}{l}1.55^{\mathrm{a}} \\
(6.83) \\
{[0.00]} \\
\end{array}$ & $C$ & $\begin{array}{l}1.12^{\mathrm{a}} \\
(11.96) \\
{[0.00]}\end{array}$ & $C$ & $\begin{array}{l}1.97^{\mathrm{a}} \\
(15.35) \\
{[0.00]} \\
\end{array}$ \\
\hline \multicolumn{8}{|l|}{ Diagnostic tests } \\
\hline Diagnostic tests & BIST100 = f(PI) & \multicolumn{2}{|c|}{ BIST100 = f(MCI) } & \multicolumn{2}{|c|}{ BIST100 = f(F) } & \multicolumn{2}{|c|}{ BIST100 = $f(V)$} \\
\hline$L M$ & $1.14[0.32]$ & \multicolumn{2}{|c|}{$0.99(0.32]$} & \multicolumn{2}{|c|}{$2.16(0.15]$} & \multicolumn{2}{|c|}{$1.39(0.25]$} \\
\hline BPG & $0.38[0.82]$ & \multicolumn{2}{|c|}{$1.20[0.30]$} & \multicolumn{2}{|c|}{$0.80[0.60]$} & \multicolumn{2}{|c|}{$1.88[0.12]$} \\
\hline Ramsey reset test & $0.11[0.73]$ & \multicolumn{2}{|c|}{$0.36[0.54]$} & \multicolumn{2}{|c|}{$0.24[0.62]$} & \multicolumn{2}{|c|}{$0.08[0.77]$} \\
\hline
\end{tabular}

Note: The values in ( ) represent the statistical values of $t$ tests; the values in [ ] represent probability (p) values, a: significant at the $1 \%$ level, b: significant at the $5 \%$ level; $k$ represents the number of independent variables. LM refers to Breusch-Godfrey LM autocorrelation and BPG to Breusch-Pagan-Godfrey heteroscedasticity tests. 
according to the AIC were estimated after the cointegration relationship was established. The long-term coefficients of the ARDL models are stated in Table 6.

It is found in Table 6 that the BIST100 variable has not been affected by the PI and F variables in the long term, while the $\mathrm{MCl}$ variable has a negative and statistically significant effect on the BIST100 variable in the long term. It has been established that a $1 \%$ increase in the $\mathrm{MCl}$ variable decreases the BIST100 variable by $0.28 \%$. Besides, it is concluded in the analysis that the effect of the $V$ variable on the BIST100 variable is positive and statistically significant in the long term. It is established that a $1 \%$ increase in the $\mathrm{V}$ variable increases the BIST100 variable by $0.16 \%$. It can be seen in Table 6 that the estimated ARDL models are problem-free - in other words, there are no autocorrelation, no variance problems and the models are set in the correct form (because the probability values of Breusch-Godfrey LM, Breusch-Pagan-Godfrey and Ramsey Reset test statistics are greater than 0.10 ).

The Short-term coefficients of error correction models estimated in the ARDL method are shown in Table 7.

When the short-term coefficients are examined in Table 7, it is concluded that the coefficients of the PI, F and $\mathrm{MCl}$ variables are negative and the coefficients of the $\mathrm{V}$ variable are positive. It is determined that a $1 \%$ increase in the $\mathrm{V}$ variable in the short term increases the BIST 100 variable by $0.38 \%$, while a $1 \%$ increase in the $\mathrm{PI}, \mathrm{F}$ and $\mathrm{MCl}$ variables in the short term decreases the BIST 100 variable by $0.07 \%, 0.08 \%$ and $0.61 \%$, respectively. While the PI (t-period values) variable affects BIST100 negatively, it can be seen that the lag value of the variable $(\mathrm{PI}(-1))$ does not have an effect. It can be seen that all coefficients of the $\mathrm{MCl}$ and $\mathrm{F}$ variables are negative and statistically significant, and the lag values of the $\mathrm{MCl}$ and $\mathrm{F}$ variables $(\mathrm{MCl}(-1), \mathrm{MCl}(-2), \mathrm{MCl}(-3)$, $F(-1), F(-2))$ have a negative effect. In other words, it is concluded that the increase in the lag values of the $\mathrm{MCl}$ and $F$ variables affects the $t$-period value of the BIST100 variable negatively.

It is concluded that the ECT(-1) coefficient in the ARDL error correction models that is estimated as BIST100 $=f(P I), B I S T 100=f(F), B I S T 100=f(M C l)$ and $\mathrm{BIST} 100=\mathrm{f}(\mathrm{V})$ is $-1.07,-0.87,-1.11$ and -0.69 respectively. The fact that the ECT(-1) coefficient is negative and statistically significant is construed as showing that the short-term deviations will be eliminated in the following periods. The fact that the coefficient of the error correction term in the BIST100 $=f(P I)$ and $\mathrm{BIST} 100=\mathrm{f}(\mathrm{MCl})$ models is greater than -1 shows that the deviations in the short term will fluctuate and will be balanced in the longer term.

In addition, with the use of CUSUM and CUSUM-SQ graphics, it has been determined that the coefficients

Table 7: Short-Term Coefficients (Error Correction Model)

\begin{tabular}{|c|c|c|c|c|c|c|c|}
\hline \multicolumn{2}{|c|}{ BIST100 = f(PI) } & \multicolumn{2}{|c|}{ BIST100 = $f(F)$} & \multicolumn{2}{|c|}{ BIST100 = f(MCI) } & \multicolumn{2}{|c|}{ BIST100 = $f(V)$} \\
\hline $\operatorname{ARDL}(1,2)$ & & $\operatorname{ARDL}(4,3)$ & & $\operatorname{ARDL}(1,4)$ & & $\operatorname{ARDL}(2,2$ & \\
\hline$P I$ & $\begin{array}{l}-0.07^{\mathrm{b}} \\
(-1.96) \\
{[0.05]}\end{array}$ & $F$ & $\begin{array}{l}-0.08^{b} \\
(-2.26) \\
{[0.02]}\end{array}$ & $M C I$ & $\begin{array}{l}-0.61^{a} \\
(-3.53) \\
{[0.00]}\end{array}$ & $\boldsymbol{V}$ & $\begin{array}{l}0.38^{\mathrm{a}} \\
(4.98) \\
{[0.00]}\end{array}$ \\
\hline \multirow[t]{2}{*}{$P I(-1)$} & \multirow[t]{2}{*}{$\begin{array}{l}-0.005 \\
(-0.12) \\
{[0.90]}\end{array}$} & $F(-1)$ & $\begin{array}{l}-0.10^{\mathrm{a}} \\
(-2.60) \\
{[0.01]}\end{array}$ & $\begin{array}{l}\mathrm{MCl}(-1) \\
M C l(-2)\end{array}$ & $\begin{array}{l}-0.77^{\mathrm{a}} \\
(-3.79) \\
{[0.00]} \\
-0.57^{\mathrm{a}} \\
(-2.93) \\
{[0.00]}\end{array}$ & \multirow[t]{2}{*}{$V(-1)$} & \multirow[t]{2}{*}{$\begin{array}{l}-0.02^{\mathrm{a}} \\
(-0.97) \\
{[0.33]}\end{array}$} \\
\hline & & $F(-2)$ & $\begin{array}{l}-0.06^{c} \\
(-1.77) \\
{[0.08]}\end{array}$ & $M C I(-3)$ & $\begin{array}{l}-0.35^{b} \\
(-1.92) \\
{[0.05]}\end{array}$ & & \\
\hline$E C T(-1)$ & $\begin{array}{l}-1.07^{a} \\
(-12.49) \\
{[0.00]}\end{array}$ & $E C T(-1)$ & $\begin{array}{l}-0.87^{a} \\
(-9.02) \\
{[0.00]}\end{array}$ & $E C T(-1)$ & $\begin{array}{l}-1.11^{a} \\
(-16.37) \\
{[0.00]}\end{array}$ & $E C T(-1)$ & $\begin{array}{l}-0.69^{a} \\
(-6.02) \\
{[0.00]}\end{array}$ \\
\hline
\end{tabular}

Note: $\mathrm{a}, \mathrm{b}$ and $\mathrm{c}$ represent the significance levels: $1 \%, 5 \%$ and $10 \%$ respectively; the values in ( ) represent the statistical values of $\mathrm{t}$ test, the values in [] represent the probability $(p)$ values, and ECT $(-1)$ represents the error correction coefficient. The coefficients of the independent variables in the model are given in the table. 
of the $\mathrm{DL}$ and $\mathrm{ARDL}$ models are stable and there is no structural break. CUSUM and CUSUM-SQ graphics of DL and ARDL models are given in the appendix.

With the help of the cross-correlation function, cross-correlation coefficients between the variables PI, $\mathrm{F}, \mathrm{MCl}, \mathrm{V}$ and BIST100 are calculated up to $\mathrm{k}= \pm 12$ lag. Figure 1 shows $k$ taking values between -12 and +12 on the horizontal axis and calculated cross-correlation coefficients on the vertical axis. The effects on the BIST100 variable of the current, lead and lag values of the variables $\mathrm{PI}, \mathrm{F}, \mathrm{MCl}$ and $\mathrm{V}$ can be seen visually in the graphs obtained.

As can be seen in Figure 1, the current, past and future values of the cross-correlation coefficients calculated between the PI-BIST100, F-BIST100 and $\mathrm{MCI}-\mathrm{BIST} 100$ variables are negative, and the current, past and future values of the coefficients calculated between the V-BIST100 variables are positive. In other words, it can be said that the effects of current, past and future values of the variables $\mathrm{PI}, \mathrm{F}$ and $\mathrm{MCl}$ on the BIST100 variable are negative, while the effects of current, past and future values of the variable $V$ on the BIST100 variable are positive.
It seems that the findings obtained from the $\mathrm{DL}$ causality test, ARDL and cross-correlation methods support each other. It can be seen that the panic, fear and media coverage indices affect the BIST100 return negatively, when the findings obtained from the analysis are evaluated together.

\section{DISCUSSION AND CONCLUSION}

As is known from the finance literature, the effect of investor sentiment on the financial markets in the framework of a behavioural finance approach is a very hot topic (Baker and Wurgler, 2007; De Long et al., 1990; Shleifer and Vishny, 1997; Shleifer and Summers, 1990). Studies on investor sentiment are important in revealing the biases of investors in stock market forecasts and providing an opportunity to earn returns on these biases (Fisher and Statman, 2000: 16). In this context, investor sentiment is defined as the belief regarding future cash flows and investment risk, and it is claimed that this is difficult to confirm using the existing data (Baker and Wurgler, 2007). On the other hand, it is stated that certain events can create positive or negative investor sentiment and affect stock returns (Donadelli
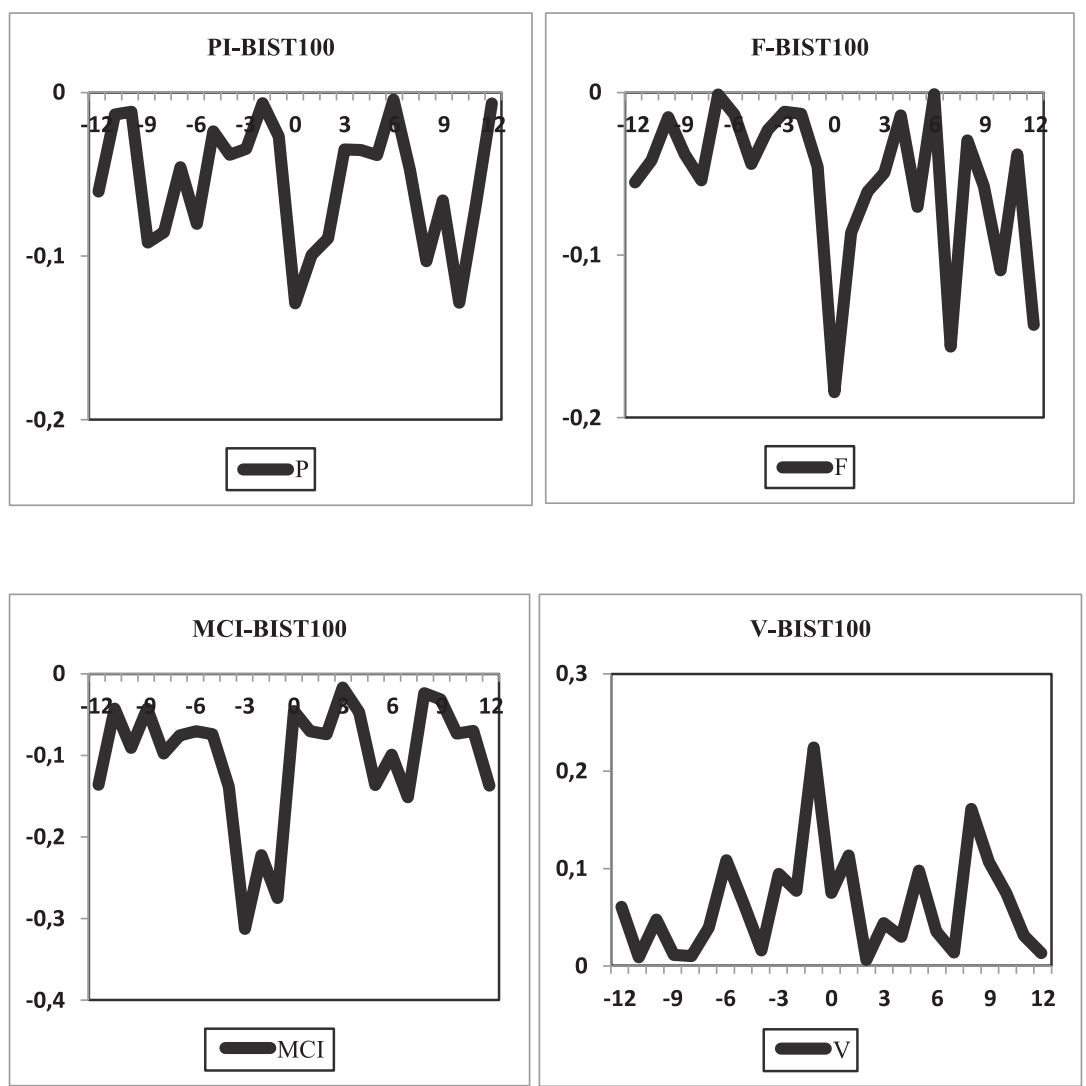

Figure 1: Cross-Correlation Coefficients (Cross-Correlation Coefficients Between P, F, MCI, V and BIST100) 
et al., 2017). Support this statement, the effect of investor sentiment is striking when looking at the effects of the emergence of the COVID-19 pandemic on markets such as the FTSE, the Dow Jones Industrial Average and the Nikkei.

The present study analyses the relationship between investor sentiment caused by COVID-19-related media coverage and the BIST100 Index return. Since it is difficult to observe investor sentiment, different variables are used as sentiment proxies in the related studies. Among these studies, Tetlock (2007) determines that high levels of media pessimism relate to low investor sentiment. In this context, panic, fear, media coverage and vaccine indices are used in the present study as investor sentiment proxies based on media coverage of COVID-19, consistent with Cepoi's (2020) and Haroon and Rizvi's (2020) studies. In the first stage of the analysis of this study, the Dolado-Lütkepohl causality analysis method is used to test the relationship between media-coverage-related investor sentiment proxies and BIST100 returns, and it is found that media-coverage-based investor sentiment indices are related to returns, consistent with the findings of Tetlock (2007) and Haroon and Rizvi (2020).
In the framework of theoretical assumptions regarding investor sentiment, it is expected that there will be a positive relationship between investor sentiment and contemporaneous returns, and that this relationship will be reversed in the long run (Smales, 2017; Tetlock, 2007). Within this scope, ARDL analysis was performed in the second stage of analyses in the present study to test the short- and long-run relationship between investor sentiment and returns. In addition, cross-correlation analysis was performed as a robustness check. We found evidence that the short- and long-run relationship between investor sentiment and returns are the same, indicating that this relationship does not change in the long run, as investor sentiment theory suggests it will. The findings obtained point to the prediction of information theory that short-run returns will persist indefinitely. Lastly, it seems difficult to make an absolute judgement on the prediction of 'investor sentiment theory' regarding news, as the COVID-19 pandemic continues. In addition, Verma et al. (2008) state that rational investor sentiment also may affect stock market returns. In accordance with this view, the long-run results obtained in this study may point to rational investor sentiment that needs to be investigated in more detail after the COVID-19 pandemic. 


\section{REFERENCES}

Al-Awadhi, A.M., Alsaifi, K., Al-Awadhi, A. and Alhammadi, S. (2020). Death and contagious infectious diseases: Impact of the COVID-19 virus on stock market returns, Journal of Behavioral and Experimental Finance, 27, 100326.

Albulescu, C. (2020). Coronavirus and financial volatility: 40 days of fasting and fear, 2020, SSRN Electronic Journal. http://dx.doi.org/10.2139/ssrn.3550630

Ali, N., Nassir, A., Hassan, T. and Abidin, S. (2010). Short run stock overreaction: Evidence from Bursa Malaysia, International Journal of Economics and Management, 4(2), 319-333.

Ashraf, B.N. (2020). Stock markets' reaction to Covid-19: Cases or fatalities? Research in International Business and Finance, 54, 101249. http://dx.doi.org/10.2139/ssrn.3585789

Baig, A.S., Butt, H.A., Haroon, O. and Rizvi, S. (2020). Deaths, panic, lockdowns and US equity markets: The case of COVID-19 pandemic, Finance Research Letters, 101701. https://doi. org/10.1016/j.frl.2020.101701

Baker, M. and Stein, J.C. (2004). Market liquidity as a sentiment indicator, Journal of Financial Markets, 7(3), 271-299.

Baker, M. and Wurgler, J. (2006). Investor sentiment and the cross-section of stock returns. Journal of Finance, American Finance Association, 61(4), 1645-1680.

Baker, M. and Wurgler, J. (2007). Investor sentiment in the stock market, Journal of Economic Perspectives, 21 (2), 129-152. DOI: $10.1257 /$ jep.21.2.129

Baker, S.R., Bloom, N., Davis, S.J., Kost, K.J., Sammon, M.C. and Tasaneeya, V. (2020). The unprecedented stock market impact of COVID-19. NBER Working Papers 26945. Cambridge, MA: National Bureau of Economic Research.

Bathia, D. and Bredin, D. (2013). An examination of investor sentiment effect on $\mathrm{G} 7$ stock market returns, The European Journal of Finance, 19(9), 909-937. DOI: 10.1080/1351847X.2011.636834

Becker, R., Endes, W. and Lee, J. (2006). A stationarity test in the presence of an unknown number of smooth breaks, Journal of Time Series Analysis, 3(5), 381-409.

Bollen, J., Mao, H. and Zeng, X. (2011). Twitter mood predicts the stock market, Journal of Computational Science, 2(1), $1-8$.

Caswell, M. (2020). IAG reports $€ 2.2$ billion second quarter loss. Business Traveller, 31 July. www.businesstraveller.com/ business-travel/2020/07/31/iag-reports-e2-2-billion-second-quarter-loss, (Accessed 31 July 2020).

Cepoi C.O. (2020). Asymmetric dependence between stock market returns and news during COVID-19 financial turmoil, Finance Research Letters, 36, 101658. https://doi. org/10.1016/j.frl.2020.101658

Chen, M.H., Jang, S.S. and Kim, W.G. (2007). The impact of the SARS outbreak on Taiwanese hotel stock performance: An event-study approach, International Journal of Hospitality Management, 26(1), 200-212. https://doi.org/10.1016/j. ijhm.2005.11.004
Chen, M.-P., Lee, C.-C., Lin, Y.-H. and Chen, W.-Y. (2018). Did the S.A.R.S. epidemic weaken the integration of Asian stock markets? Evidence from smooth time varying cointegration analysis, Economic Research-Ekonomska Istraživanja, 31(1), 908-926. DOI: 10.1080/1331677X.2018.1456354

Christopoulos, D.K. and León-Ledesma, M.A. (2010). Smooth breaks and non-linear mean reversion: Post-Bretton Woods real exchange rates, Journal of International Money and Finance, 29(6), 1076-1093. DOI: 10.1016/j.jimonfin.2010.02.003.

CNBC (2020). Norwegian Air cancels 97 Boeing planes, claims compensation. 29 June. https://www.cnbc. com/2020/06/29/norwegian-air-cancels-97-boeing-planes-claims-compensation.html, (Accessed 29 June 2020).

Da, Z., Engelberg, J. and Gao, P. (2015). The sum of all fears investor sentiment and asset prices, The Review of Financial Studies, 28(1), 1-32.

De Bondt, Werner F.M. and Thaler, R. (1985). Does the stock market overreact? The Journal of Finance, 40(3), 793-805. DOI: $10.2307 / 2327804$

De Long, J., Shleifer, A., Summers, L.and Waldmann, R. (1990). Noise trader risk in financial markets, Journal of Political Economy, 98(4), 703-738.

Destek, M.A. and Okumuş, İ. (2016). Satın Alma Gücü Paritesi Hipotezi Geçerliliğinin Fourier Birim Kök Testleri ile İncelenmesi: OECD Ülkeleri Örneği, Gaziantep University Journal of Social Sciences, 15(1), 73-87.

Dickey, D.A. and Fuller, W.A. (1981). Likelihood ratio statistics for autoregressive time series with a unit root, Econometrica, 49(4), 1057-1072.

Dolado, J.J. and Lütkepohl, H. (1996). Making wald tests work for cointegrated VAR systems, Econometric Theory, 15(4), 369-386.

Donadelli, M., Kizys, R. and Riedel, M. (2017). Dangerous infectious diseases: Bad news for Main Street, good news for Wall Street? Journal of Financial Markets, 35(C), 84-103.

Enders, W. and Lee, J. (2012). The flexible Fourier form and the Dickey-Fuller type unit root tests, Economics Letters, 117, 196-199.

Engelhardt, N., Krause, M., Neukirchen, D. and Posch, P. (2020). What drives stocks during the corona-crash? News attention vs. rational expectation, Sustainability, MDPI 12(12), $1-12$.

Fama, E.F. (1995). Random walks in stock market prices, Financial Analysts Journal, 51(1), 75-80. DOI: 10.2469/faj.v51. n1.1861

Fisher, K.L. and Statman, M. (2000). Investor sentiment and stock returns, Financial Analysts Journal, 56(2), 16-23. www.jstor.org/stable/4480229

French, J. (2018). Market moods: An investor sentiment event study, Foresight, 20(5), 488-506. 
Haroon, O. and Rizvi, S. (2020). COVID-19: Media coverage and financial markets behavior - a sectoral inquiry, Journal of Behavioral and Experimental Finance, 27, 100343. https:// doi.org/10.1016/j.jbef.2020.100343

He, P., Sun, Y., Zhang, Y. and Li, T. (2020). COVID-19's impact on stock prices across different sectors: An event study based on the Chinese stock market, Emerging Markets Finance and Trade, 56(10), 2198-2212.

Hon, M.T., Strauss, J. and Yong, S.-K. (2004). Contagion in financial markets after September 11: Myth or reality? Journal of Financial Research, 27(1), 95-114. DOI: 10.1111/j.14756803.2004.00079.x

ILO (2020). COVID-19 and the world of work: Impact and policy responses. ilo.org/global/topics/coronavirus (Accessed 1 May 2020).

Jones, L., Palumbo, D. and Brown, D. (2020). Coronavirus: A visual guide to the economic impact, www.bbc.com/news/ business-51706225 (Accessed 30 June 2020).

Kahneman, D. and Tversky, A. (1979). Prospect theory: An analysis of decision under risk. Champaign: University of IIlinois at Urbana-Champaign's Academy for Entrepreneurial Leadership Historical Research Reference in Entrepreneurship. https://ssrn.com/abstract=1505880

Kandır, S.Y., Cerci, G. and Uzkaralar, O. (2013). Investor sentiment proxies: An example of closed end fund discount and consumer confidence index, Journal of BRSA Banking and Financial Markets, 7(2), 55-75.

Kaplanski, G. and Levy, H. (2010). Sentiment and stock prices: The case of aviation disasters, Journal of Financial Economics, 95(2), 174-201. https://ssrn.com/abstract=1084533

Kaplanski, G. and Levy, H. (2014). Sentiment, irrationality and market efficiency: The case of the 2010 FIFA World Cup, Journal of Behavioral and Experimental Economics, 49(C), 35-43.

Lee, H.S. (2020). Exploring the initial impact of COVID-19 sentiment on US stock market using big data, Sustainability, 12(16), 1-16.

$\mathrm{Li}, \mathrm{K}$. (2018). Do high-frequency fleeting orders exacerbate market illiquidity? Electronic Commerce Research, 18, 241-255.

Liu, H., Manzoor, A., Wang, C., Zhang, L. and Manzoor, Z. (2020). The COVID-19 outbreak and affected countries stock markets response, International Journal of Environmental Research and Public Health, 17(8), 2800.

Mian, G.M. and Sankaraguruswamy, S. (2012). Investor sentiment and stock market response to earnings news, The Accounting Review, 87(4), 1357-1384.

Narayan, P.K. and Smyth, R. (2006). What determines migration flows from low-income to high-income countries? An empirical investigation of Fiji-U.S. migration 1972-2001, Contemporary Economic Policy, 24(2), 332-342.
Oliveira-Brochado, A. (2019). Google search-based sentiment indexes, IIMB Management Review, in press. https://doi. org/10.1016/j.iimb.2019.10.015

Pesaran, M.H., Shın, Y. and Smıth, R.J. (2001). Bounds testing approaches to the analysis of level relationships, Journal of Applied Econometrics, 16, 289-326.

Reuters (2020). Air France-KLM loss gives first taste of coronavirus impact. 7 May. www.reuters.com/article/us-air-franceklm-results/air-france-klm-loss-gives-first-taste-of-coronavirus-impact-idUSKBN22J0IZ, (Accessed 7 May 2020).

Salisu, A.A. and Vo, X.V. (2020). Predicting stock returns in the presence of COVID-19 pandemic: The role of health news, International Review of Financial Analysis, 71, 101546. https://doi.org/10.1016/j.irfa.2020.101546

Schell, D., Mei, W. and Toan Luu Duc, H. (2020). This time is indeed different: A study on global market reactions to public health crisis. 16 April. https://ssrn.com/abstract=3577418

Sevüktekin, M. and Nargeleçekenler, M. (2010). Ekonometrik Zaman Serileri Analizi Eviews Uygulamalı. Nobel Yayın Dağıtım 3. baskı, Ankara.

Shleifer, A. and Summers, L.H. (1990). The noise trader approach to finance, Journal of Economic Perspectives, 4 (2), 19-33.

Shleifer, A. and Vishny, R.W. (1997). The limits of arbitrage, Journal of Finance, 52(1). https://ssrn.com/abstract $=8043$

Shu, H.-C. (2010). Investor mood and financial markets, Journal of Economic Behavior \& Organization, 76(2), 267-282.

Smales, L.A. (2017). The importance of fear: investor sentiment and stock market returns. Applied Economics, 49(34), 3395-3421.

Tas, O. and Sen, M.C. (2019). The comparative analysis of investor sentiment effect on two major earthquakes and tsunami incidents, PressAcademia Procedia, 10, 12-16.

Tetlock, P.C. (2007). Giving content to investor sentiment: The role of media in the stock market, Journal of Finance 62(3), 1139-1168.

Verma, R., Baklaci, H. and Gokce S. (2008). The impact of rational and irrational sentiments of individual and institutional investors on DIAA and S\&P500 index returns, Applied Financial Economics, 18(16), 1303-1317.

World Bank, 2020. Assessing the impact and policy responses in support of private-sector firms in the context of the COVID-19 pandemic. Equitable Growth, Finance and Institutions, COVID-19 Notes, Finance Series. Washington DC, World Bank. http://pubdocs.worldbank.org/ en/879461586478617078/COVID-19-Outbreak-Supportto-Firms.pdf, (Accessed 26 March 2020). 


\section{Appendix}
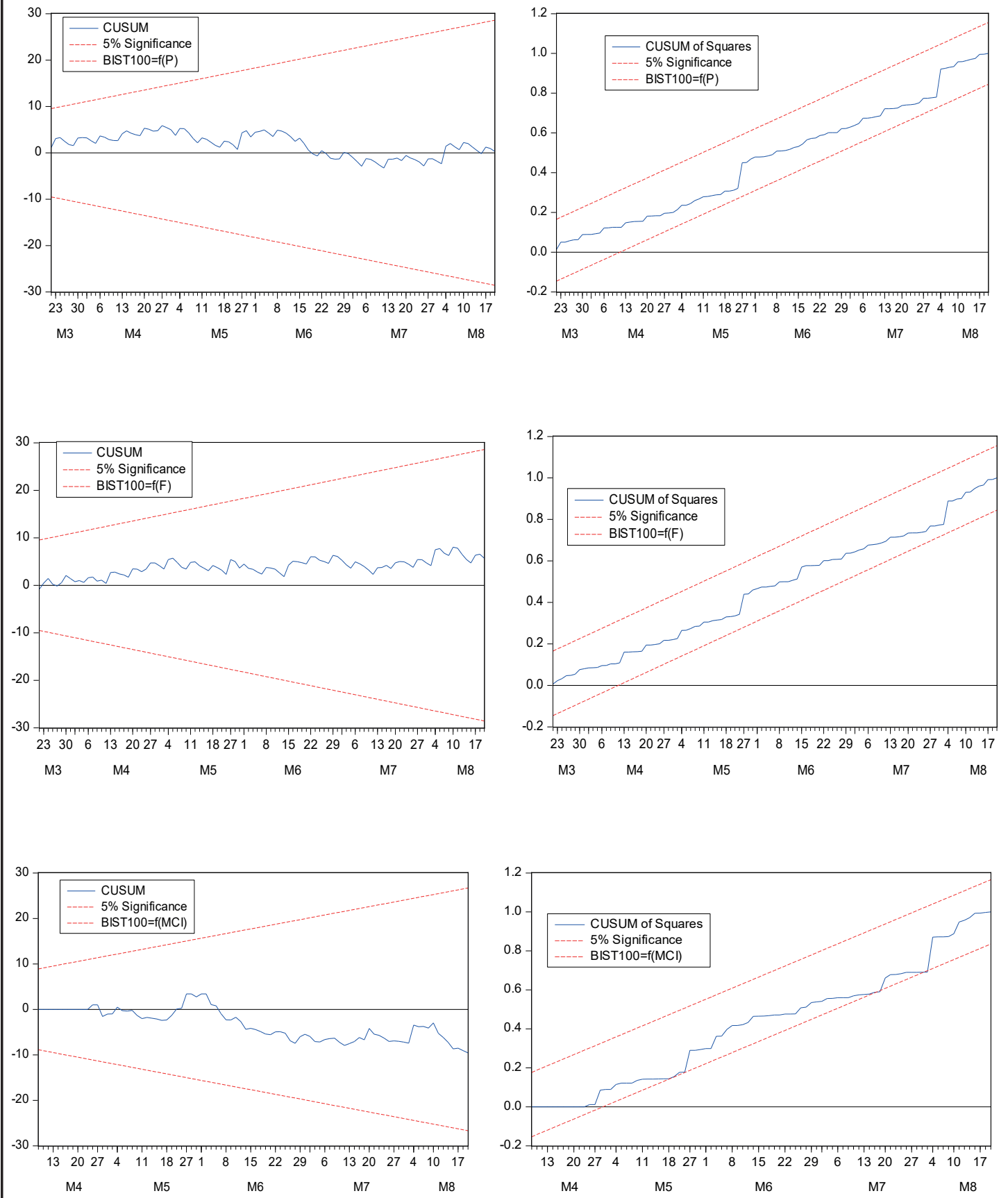

Figure 1: CUSUM and CUSUM-SQ Charts of DL Models 


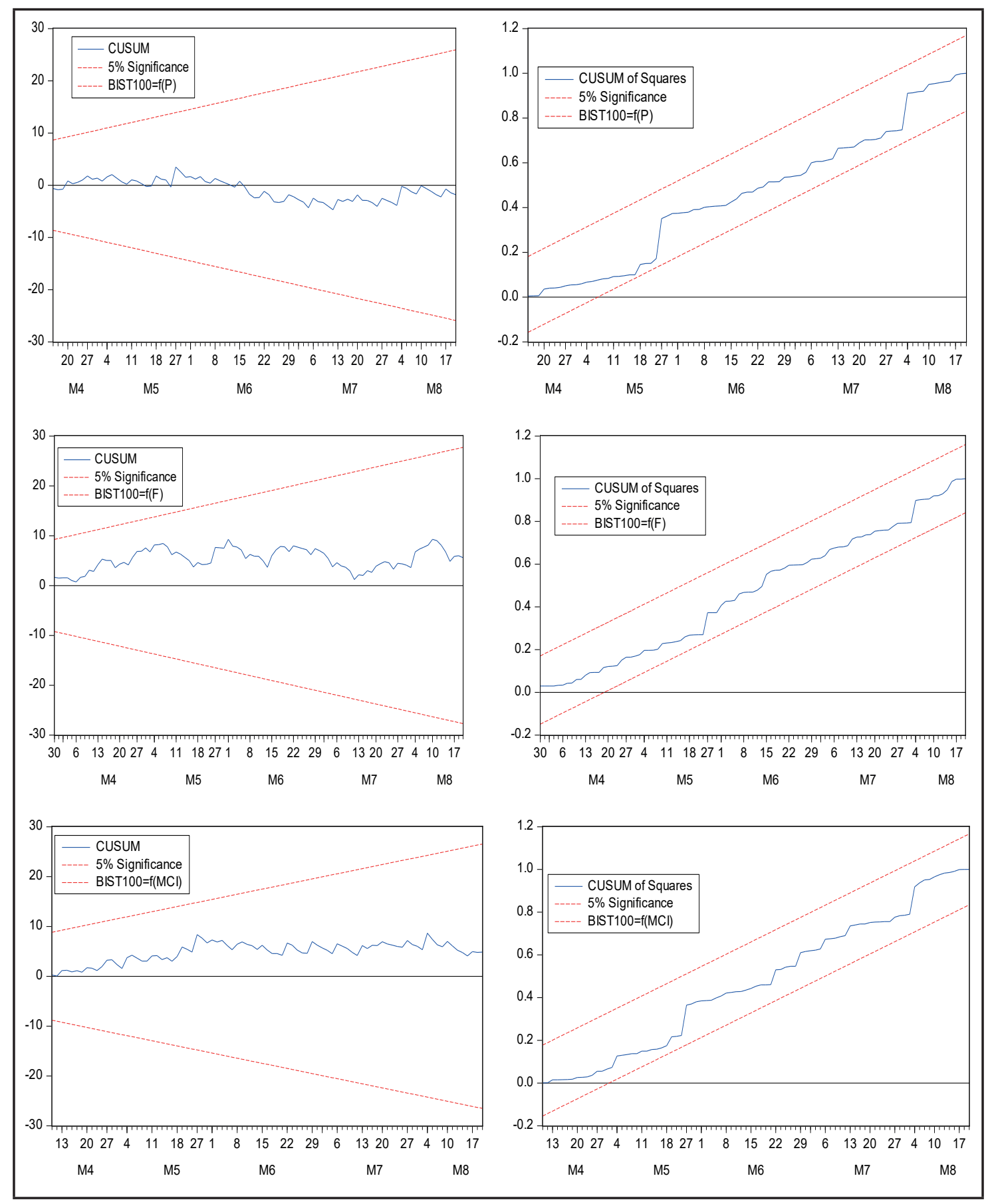

Figure 2: CUSUM and CUSUM-SQ Charts of ARDL Model 